\title{
Research on outsourcing level measurement and influencing factors of China's agricultural listed companies
}

\author{
REN Jianhua ${ }^{1}$, LEI Hongzhen ${ }^{2}$ * \\ ${ }^{1}$ International Business School, Shaanxi Normal University, Xi'an, 710119, China \\ ${ }^{2}$ Economics and Management School, Shaanxi Xueqian Normal University, Xi'an 710100, China
}

\begin{abstract}
Outsourcing is beneficial for enterprises to integrate production factors, strengthen core forces and realize value chain appreciation. Based on the data of 42 agricultural listed companies from 2,015 to 2,019 , the outsourcing level of agricultural enterprises was measured, and the influencing factors of agricultural enterprise outsourcing were analyzed. The results show that the level of outsourcing of agricultural enterprises in 2015 to 2,019 showed a slow downward trend, the outsourcing level of agricultural enterprises has policy continuity, and the outsourcing level of the current period is affected by the outsourcing level of the previous period; the larger the market scale, the higher the proportion of business outsourcing; and the transaction costs significantly inhibit the outsourcing decision of agricultural enterprises. Finally, the paper puts forward the policy suggestions to promote the healthy development of the agricultural outsourcing market.
\end{abstract}

\section{Introduction}

With the rapid development of information technology and the intensification of market competition, it has become an important mode of production, operation and management for enterprises to control the value chain link that can generate core competence internally and to subcontract non strategic operations. As the primary agricultural products required by agricultural enterprises are exposed to greater natural and market risks, with high transaction costs and uncertainties, the way of obtaining raw materials is an important factor considered by agricultural enterprises in the operation process. Therefore, business outsourcing has become one of the modes for agricultural enterprises to integrate their supply chain, which can save transaction costs compared with market procurement. Compared with the integration, it can reduce the hierarchical structure. Production outsourcing has become the choice of many agricultural enterprises and plays an increasingly important role in the production of enterprises.

Due to the rapid development of agricultural enterprises and the important role of agricultural enterprises in the national economy, this paper takes agricultural enterprises as an example to analyze the motivation of enterprise outsourcing, on this basis, designs a method to measure the degree of outsourcing of agricultural enterprises, and analyzes the relevant factors from an empirical perspective, in order to seek a reasonable solution for the development of outsourcing business activities of agricultural enterprises in China. And provide suggestions for them to carry out outsourcing activities more effectively.

\section{2 literature review}

The earliest research of outsourcing can be traced back to the paper "the Nature of the Firm" by economist Ronald H. Coase, in 1937. Since then, a large number of scholars have begun to pay attention to such issues as "make-or-buy decision", whether outsourcing can improve corporate performance, and the decisionmaking basis for outsourcing and vertical integration. For the consideration and answer to these questions, scholars initially started from the transaction cost theory, and found that cost saving is the most important driving force for enterprises to contract out. Abraham \& Taylor $(1,996)^{[1]}$ pointed out that when considering production costs, especially labor costs, enterprises prefer to purchase and produce by themselves. The cost of purchase not only includes the price of parts and components, but also includes the transportation expenses incurred in the purchase, the cost of breach of contract caused by incomplete contracts, and the transaction costs caused by factors such as the specificity of assets. In addition to transaction costs, there are other factors that affect outsourcing decisions. Kimura $(2,001)^{[2]}$ and Tomiura $(2,004)^{[3]}$ analyzed the influencing factors of the outsourcing decision of manufacturing industry in Japan from the enterprise level; Mazzanti $(2,009)^{[4]}$ analyzed the influencing factors of the outsourcing decision of manufacturing industry in Rome, Emilia (a region in Italy); Capasso et al. $(2,011)^{[5]}$ studied the outsourcing of manufacturing products in major industrial zones in Italy and the decisive factors of outsourcing strategy formulation.

${ }^{*}$ Corresponding author: leihongzhen $@ 21 \mathrm{cn} . c 0 m$ 
At present, the research on the influencing factors and decision-making of agricultural enterprise outsourcing mainly focuses on the theoretical level, or from the perspective of farmers to analyze agricultural production outsourcing. Qiu Tongwei $(2,018)^{[6]}$ based on the classic division of labor theory, discussed the complete replacement of self-sufficiency and outsourcing services, the relevance of partial replacement and complete complement, and the impact on the vertical division of labor in agriculture; Sun Dingqiang, Misgina Asmelas, Lu Yutong, et al. $(2,018)^{[7]}$, from the perspective of operation quality supervision and risk preference of farmers, considered that the significant degree of risk preference and operation quality supervision of farmers affected the demand for outsourcing services in different production links of farmers to a certain extent.In the research similar to the research topic in this paper, Chen Mei and Maoning $(2,015)^{[8]}$ based on the transaction cost theory and option transaction governance theory, discussed the comprehensive impact of the uncertainty of the counterparty's opportunistic behavior and the uncertainty of the objective environment on the selection of strategic raw material investment governance model, and believed that for China's dairy enterprises, the close relationship governance model (such as cooperatives and wars)Strategic alliance) is a better management model for raw milk investment. Cao Bingxue and Zheng Fengtian $(2,017)^{[9]}$ analyzed the influencing factors of the choice of the organizational structure of the food enterprises in China by building an incomplete contract model including consumers, food terminal enterprises and food processing enterprises with the focus on the quality of consumer food as the entry point. The results showed that the degree of focus on the quality of consumers, the technology of the subcontractor and the factors of asset specificity would affect the food enterprises Organization structure selection.

In summary, at present, the research on the motivation of outsourcing mainly focuses on industrial enterprises, while few researches related to the outsourcing of agricultural enterprises mainly focus on theoretical analysis or focus on a certain sub industry, such as animal husbandry and food processing enterprises, and the research on the influencing factors of the outsourcing of agricultural enterprises is limited. Therefore, the contributions of this paper mainly include: (1) measuring the outsourcing level of agricultural listed companies from 2,015 to 2,019, and comparing the differences between the outsourcing levels of different sub sectors; (2) analyzing the impact of corporate characteristics on the outsourcing level, identifying the main factors affecting the outsourcing decisions of agricultural sub sectors.

\section{Basic situation of outsourcing of agricultural enterprises in China}

This paper refers to the definition of international outsourcing by Feenstra et al. $(1,996)$ to construct the outsourcing coefficient of agricultural listed companies, which is to measure the degree of outsourcing by the proportion of the intermediate input of enterprises in the total production expenditure. Including: intermediate input includes direct materials, manufacturing input, management input and business input; total expenditure is the sum of intermediate input, labor input and capital input. Based on this, the outsourcing level of listed agricultural companies in China from 2,015 to 2,019 is calculated by using the financial data published publicly. The sample enterprises include a total of 46 enterprises under the category of "agriculture, forestry, animal husbandry and fishery" under the industry classification of CSRC on the website of flush finance and economics.

This study takes the data of 45 agricultural listed companies in 2019 as an example to understand the basic situation of agricultural enterprises. The outsourcing level of 45 enterprises in the past 5 years is calculated. Table 1 compares the average outsourcing level of agricultural listed companies in different sub sectors between 2,015 and 2,019. Horizontally, the highest level of outsourcing is aquaculture $(66.27 \%)$, and the lowest level is forestry enterprises (61.93\%). From the vertical perspective, the overall outsourcing level of agricultural listed companies decreased slightly, and the average outsourcing proportion decreased from $67.64 \%$ in 2015 to $64.91 \%$ in 2019 . There is no obvious annual change law for each sub industry. However, for any period, the outsourcing level of aquaculture enterprises is higher than that of other sub industries except comprehensive industries.

Table 1. Outsourcing degree of agricultural enterprises

\begin{tabular}{|c|c|c|c|c|c|}
\hline $\begin{array}{c}\text { Agricultural } \\
\text { segmentation }\end{array}$ & $\mathbf{2 0 1 5}$ & $\mathbf{2 0 1 6}$ & $\mathbf{2 0 1 7}$ & $\mathbf{2 0 1 8}$ & $\mathbf{2 0 1 9}$ \\
\hline Aquaculture & $70 \%$ & $67 \%$ & $66 \%$ & $62 \%$ & $66 \%$ \\
\hline planting & $66 \%$ & $65 \%$ & $63 \%$ & $63 \%$ & $59 \%$ \\
\hline Forestry & $67 \%$ & $61 \%$ & $63 \%$ & $65 \%$ & $65 \%$ \\
\hline Fisheries & $61 \%$ & $66 \%$ & $66 \%$ & $62 \%$ & $62 \%$ \\
\hline Agribusiness & $74 \%$ & $73 \%$ & $72 \%$ & $71 \%$ & $72 \%$ \\
\hline
\end{tabular}

Through the simple analysis of the above data, it can be seen that the outsourcing level of agricultural listed companies is relatively high, reaching more than $60 \%$, which may be affected by the particularity and complexity of agricultural products production and operation. However, there are differences in the outsourcing level of enterprises in different sub sectors, indicating that the type of industry will affect the outsourcing decision-making of enterprises to a certain extent. The scale of enterprises measured by total assets is consistent with the degree of outsourcing, i.e. the larger the scale of assets, the higher the degree of outsourcing. The relationship between the profitability measured by the net interest rate of equity and the degree of outsourcing cannot be highlighted. For enterprises with strong profitability, the level of outsourcing is not necessarily high. Therefore, in order to further investigate the impact of these factors on the level of 
enterprise outsourcing, the following will be a theoretical analysis of various factors affecting the outsourcing of agricultural enterprises.

\section{Theoretical analysis and assumptions}

A large number of scholars have shown that reducing costs is an important reason for enterprises to choose outsourcing. According to the transaction cost theory of Coase (1937) and Williamson (1985), market transaction will increase transaction cost due to opportunistic behavior, uncertainty and asset specificity, while internal control and coordination can effectively reduce transaction cost. At the same time, with the expansion of enterprise scale, the cost of internal organization and coordination will rise. When the cost of market transaction resource allocation equals to the cost of internal control and coordination, it is the boundary of enterprise existence. Therefore, traders will choose an organizational arrangement that can minimize the overall cost of their expected governance of a certain transaction relationship.

In addition, outsourcing is also affected by the limited resources of enterprises. An enterprise is an aggregate of various resources, and the resources owned by different enterprises are different. Therefore, enterprises should focus on the core business with limited resources, and separate or outsource some non core business. Thus, the company maintains a certain level of liquidity.

From the perspective of value chain theory, some scholars also believe that outsourcing is a new change of international division of labor. The international division of labor is no longer limited to the stage of product production, but extends to the entire value chain of products. The comparative advantage between countries is reflected in certain specific links of the product value chain. In order to achieve its strategy, enterprises split the entire product value chain, which drives the development of outsourcing 。

Based on the above theories, this paper proposes the factors that may affect the outsourcing decision-making of enterprises as the basis for subsequent research:

\subsection{Market share}

The larger the market size of the enterprise, the higher the cost of production organization and management, and the greater the possibility of outsourcing. And the business volume of large-scale enterprises is also large, the more outsourcing demand. However, outsourcing also includes information cost, supervision cost, default cost, etc., so it will reduce outsourcing. Therefore, the impact of enterprise scale on outsourcing decisions cannot be fully determined. In this paper, the sales revenue is used to measure the scale of the enterprise. The data is generally large, so the natural logarithm of the sales revenue of the enterprise is taken.

\subsection{Transaction costs}

The transaction costs determined by the uncertainty and frequency of transactions will affect the organizational form of the enterprise. The higher transaction costs will encourage the enterprise to carry out internal production in order to save transaction costs, and thus reduce outsourcing. Transaction costs have an impact on management costs and sales costs. Therefore, transaction costs are measured based on period costs, including management costs, sales costs and financial costs. The higher the period cost, the higher the transaction cost, the more likely the enterprise is to engage in proprietary business rather than outsourcing.

\subsection{Proportion of specific investment}

The asset specificity of an enterprise can be measured by the ratio of fixed assets to current assets. It is generally believed that the higher the asset specificity, the higher the degree of internalization, and the lower the degree of outsourcing; some scholars believe that the existence of asset specificity makes enterprises aware of the existence of opportunism and production risks, and thus more inclined to choose outsourcing production. Therefore, the impact of this indicator on outsourcing is uncertain.

\subsection{Corporate capability}

The ability of an enterprise is reflected in its ability to use, convert and integrate resources. Outsourcing is also a way of resource integration, and the stronger the ability of the enterprise, the more power and ability to grow, often involved in a longer industrial chain, the more space and autonomy for the selection of production and operation links, and the more incentive and opportunity to outsource part of the industrial chain. In addition, enterprises with strong capabilities can choose not only domestic outsourcing, but also international outsourcing. In this paper, the net interest rate of equity is used to measure the enterprise capacity, and the impact of this indicator on outsourcing is predicted to be positive.

\subsection{Research and development}

Outsourcing will stimulate innovation by reducing production costs and improving profits. Meanwhile, enterprises can engage in more $\mathrm{R} \& \mathrm{D}$ activities through outsourcing of production links, which means that enterprises with high technical ability will prefer outsourcing. This paper uses the amortization of intangible assets to measure the level of research and development of enterprises. The impact of this indicator on outsourcing is expected to be positive.

\subsection{Age of the enterprise}

The older the enterprise, the more skilled the production and operation, the more demand and ability to expand the scale of production and operation through 
outsourcing. It is expected that the impact of outsourcing is positive.

\section{Empirical analysis on the influencing factors of agricultural enterprise outsourcing}

\subsection{Model and data description}

Based on the empirical research literature and theoretical analysis, this paper considers that the level of outsourcing is affected by a series of factors such as corporate characteristics

$$
\begin{aligned}
& O_{i t}=\alpha+\beta_{1} \ln \text { Sale }_{i t}+\beta_{2} \ln P E_{i t}+\beta_{3} \ln (F / C)_{i t}+\beta_{4} \ln I E R_{i t}+\beta_{5} \ln \\
& C A_{i t}+\beta_{6} \text { Age }_{i t}+\theta_{i t}
\end{aligned}
$$

Where, $\mathrm{O}$ is the outsourcing degree, which is obtained through calculation. Represents sales revenue, used to control the size of the enterprise, PE represents period expenses, used to measure the size of transaction costs, F/C fixed assets to current assets, representing asset specificity. IER is the net interest rate of equity, which is a measure of corporate capacity. CA is the amortization amount of intangible assets, which is a measure of the technological development and application capacity of an enterprise. Age represents the age of the enterprise, expressed as the current year minus the listing year of the enterprise. Among them, the sales revenue, period expenses and amortization of intangible assets are relatively large, so the logarithm of these indicators is taken. The sample range is 2,015-2,019, a total of 5 years. In order to make the description of each variable more clear, table 2 gives a brief description of the variables used in this model and their definitions and calculation methods.

\begin{tabular}{|c|c|c|}
\hline $\begin{array}{l}\text { Variable } \\
\text { name }\end{array}$ & symbol & variable definition \\
\hline $\begin{array}{c}\text { Degree of } \\
\text { outsourcing }\end{array}$ & $\mathrm{O}$ & $\begin{array}{c}\text { Enterprise intermediate } \\
\text { investment / total investment }\end{array}$ \\
\hline sales revenue & Sale & $\begin{array}{l}\text { Annual sales revenue of the } \\
\text { company in the income } \\
\text { statement }\end{array}$ \\
\hline $\begin{array}{l}\text { Period } \\
\text { expenses }\end{array}$ & $\mathrm{PE}$ & $\begin{array}{c}\text { Selling expenses }+ \\
\text { administrative expenses }+ \\
\text { financial expenses }\end{array}$ \\
\hline $\begin{array}{c}\text { Asset } \\
\text { specificity }\end{array}$ & $\mathrm{C} / \mathrm{F}$ & Fixed assets / current assets \\
\hline $\begin{array}{l}\text { Net interest } \\
\text { rate on } \\
\text { equity }\end{array}$ & IER & Net profit / owners' equity \\
\hline Amortisation & IA & $\begin{array}{l}\text { Amortization of intangible } \\
\text { assets }\end{array}$ \\
\hline $\begin{array}{c}\text { Age of } \\
\text { enterprise }\end{array}$ & Age & $\begin{array}{c}\text { Current year-Year of } \\
\text { establishment }\end{array}$ \\
\hline
\end{tabular}

Table 2. Variable name and calculation method

\subsection{Regression results and analysis}

First of all, according to equation (1), we use the panel data of 45 agricultural listed companies to conduct annual fixed effect regression by gradually adding explanatory variables. The results of the overall test are shown in the second column of Table 3 . From the overall regression results, the impact of enterprise scale measured by sales revenue on outsourcing is positive, and statistically significant, indicating that the larger the enterprise scale, the more likely it is to outsource. The coefficient of transaction cost measured by management cost is significantly negative, which indicates that the transaction cost is inversely proportional to the degree of outsourcing. That is to say, the higher the transaction cost is, the more enterprises prefer internal production rather than outsourcing. Inconsistent with the previous research hypothesis, the impact of asset specificity on outsourcing is not significant. The profitability measured by net equity interest rate is significantly positively correlated with outsourcing, which indicates that the stronger the ability, the more likely the enterprise is to outsource. The amortization of intangible assets and the age of the enterprise are positively correlated with the degree of outsourcing, which indicates that the stronger the R \& D ability, the more focused the core link, so it is more likely to outsource the non core link. The older the enterprise is, the stronger the ability to grasp the market and deal with the risk, and the more intention to outsource. On the other hand, by comparing the coefficient, we find that the degree of outsourcing is mainly affected by the scale (coefficient is 0.0835 ) and the management fee $(-0.0761)$, which shows that the degree of outsourcing will increase by $8.35 \%$ if the sales revenue does not change by $1 \%$, while the outsourcing will decrease by $7.61 \%$ if the management fee increases by $1 \%$. Therefore, to reduce transaction costs, enterprises are more willing to package production by accident.

\subsection{Endogenous problems}

For the model (1), if the outsourcing proportion of the previous year has an impact on the outsourcing proportion of the current year, the error term $\theta$ it of the model is related to the future value $o_{t}$ of the independent variable $\mathrm{O}_{\mathrm{t}-1}$, and the strict exogenous is no longer tenable, that is, the estimation result obtained by the ordinary panel data regression method may be biased. Based on this, the System GMM dynamic panel regression method is used to overcome the problem.

The third column of Table 3 shows the GMM regression results of sample companies. The regression results show that the outsourcing degree of the current period is significantly affected by the outsourcing degree of the previous period, which indicates that the outsourcing behavior has continuity; the logarithm coefficient of sales revenue is significantly positive, which means that the agricultural listed companies with larger market scale tend to expand the production scale and occupy the market through outsourcing. The impact of transaction costs on outsourcing is significantly negative, that is, transaction costs will inhibit the 
outsourcing behavior of enterprises; asset specificity is also negatively correlated with the outsourcing level, indicating that the higher the asset specificity is, the lower the outsourcing level is. The impact of net equity interest rate and intangible assets amortization on outsourcing level in System GMM estimation does not pass the significance test. At the same time, by comparing the absolute value of each coefficient, it is found that the outsourcing degree is mainly affected by the outsourcing level, sales revenue and transaction cost of the previous period. Among them, the impact of outsourcing level and sales revenue in the previous period on outsourcing is positive, while the impact of transaction cost on current outsourcing is negative. The impact of outsourcing on asset specificity is not obvious.

Table 3. Regression results of the influencing factors of agricultural enterprise outsourcing

\begin{tabular}{|c|c|c|}
\hline Variable & basic regression & $\begin{array}{c}\text { GMM } \\
\text { regression }\end{array}$ \\
\hline $\mathrm{O}_{\mathrm{it}-1}$ & & $\begin{array}{c}0.2610^{* * *} \\
(2.98)\end{array}$ \\
\hline $\operatorname{lnSale}$ & $\begin{array}{c}0.0835 * * * \\
(6.97)\end{array}$ & $\begin{array}{c}0.0455^{* * * *} \\
(3.21)\end{array}$ \\
\hline $\operatorname{lnMF}$ & $\begin{array}{c}-0.0761 * * * \\
(-7.29)\end{array}$ & $\begin{array}{c}-0.0219 * * * \\
(-4.56)\end{array}$ \\
\hline $\mathrm{F} / \mathrm{C}$ & $\begin{array}{l}0.0001 \\
(1.42)\end{array}$ & $\begin{array}{l}-0.0530 \\
(-1.20)\end{array}$ \\
\hline IER & $\begin{array}{c}0.0001 * * * \\
(9.37)\end{array}$ & $\begin{array}{l}-0.0004 \\
(-0.07)\end{array}$ \\
\hline $\operatorname{lnIA}$ & $\begin{array}{c}0.0086^{*} \\
(2.17) \\
\end{array}$ & $\begin{array}{l}-0.0577 \\
(-1.16)\end{array}$ \\
\hline Age & $\begin{array}{c}0.0032 * \\
2.34\end{array}$ & $\begin{array}{c}0.0001^{* * * *} \\
(3.06)\end{array}$ \\
\hline CONS & $\begin{array}{c}0.3719 * * * \\
(4.69)\end{array}$ & $\begin{array}{c}0.8676^{* * *} \\
(5.02)\end{array}$ \\
\hline $\mathrm{R}^{2}$ & 0.5860 & \\
\hline Hanson test $p$ value & & 0.503 \\
\hline AR (1) test $p$ value & & 0.003 \\
\hline AR(2)test $p$ value & & 0.176 \\
\hline Obs & & 225 \\
\hline
\end{tabular}

\section{CONCLUSION AND SUGGESTIONS}

From the perspective of supply chain integration, outsourcing is conducive to agricultural enterprises to master the core strength and improve production efficiency. Based on the analysis of the influencing factors of industrial outsourcing, this paper discusses the influencing factors of outsourcing decision of agricultural listed companies, and investigates the influence of various factors on the changes of outsourcing level of planting and breeding enterprises. Through theoretical analysis and empirical research, the following conclusions are reached: (1) the outsourcing decision-making of agricultural enterprises has continuity, and the outsourcing decision-making of the current period is positively affected by the outsourcing degree of the previous period; (2) the market scale and transaction costs will promote and inhibit the outsourcing behavior of agricultural enterprises, respectively, which is shown as the higher the transaction costs, the lower the outsourcing level, and the larger the market scale, the higher the outsourcing degree. The impact of asset specificity, intangible assets and enterprise age on outsourcing is not significant. The research results also show from the side: in order to obtain the benefits of cost saving, efficiency improvement and resource optimization, we must reduce the transaction costs of business outsourcing.

\section{References}

1. Abraham, K. G., \& Taylor, S. K. . Firms' use of outside contractors: Theory and evidence. Journal of Labor Economics, 14, 3(1996)

2. Kimura, F.Fragmentation, Internalization, and Interfirm Linkages: Evidence from the Micro Data of Japanese Manufacturing Firms[A].L.K.Cheng, H.Kierzkowski. Global Production and Trade in East Asia[C].Boston, MA: Kluwer Academic Publishers, (2001)

3. Tomiura, E.Foreign Outsourcing and Firm-level Characteristics:Evidence from Japanese Manufacturers[R]. Hi-Stat Discussion Paper No.64, Institute of Economic Research of Hitotsubashi University, Tokyo (2004)

4. Mazzanti M., Montresor S., and Pini P. What Drives (or Hampers) Outsourcing? Evidence for a Local Production System of Emilia-Romagna[J].Industry \& Innovation, 16, 3(2009)

5. Capasso M., Cusmano L., and A. Morrison. The Determinants of Outsourcing and Off -shoring Strategies in Industrial Districts: Evidence from Italy[R]. DIME Final Conference, Maastricht, (2011)

6. Qiu Tongwei. The relationship between selfsupporting service and outsourcing service: a theoretical discussion on vertical division of labor in agriculture [J]. Journal of Huazhong Agricultural University (SOCIAL SCIENCE EDITION), 01(2019)

7. 2019 Sun Dingqiang, misgina asmelash, Lu Yutong, Liu Mingxuan. Link heterogeneity of operation quality supervision, risk preference and farmers' demand for production outsourcing services [J]. Agricultural technology and economy, 04 (2019)

8. Chen Mei, Mao Ning. Uncertainty, quality and safety and the choice of governance mode for strategic raw material investment of edible agricultural products -- Based on the investigation of Chinese dairy enterprises [J]. Management world, 06(2015)

9. Cao Xuebing, Zheng Fengtian. The choice of China's food enterprises: "integration" or "outsourcing" -- Based on the perspective of consumers' food quality concern $[\mathrm{J}]$. Economic theory and economic management,03 (2017) 